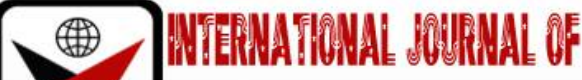

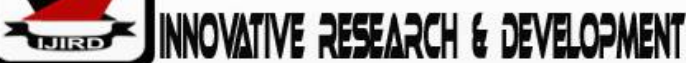

ISSN 2278 - 0211 (Online)

\section{Assessment of Teachers' Ability to Use English Language in Giving Classroom Instructions in 0-Level Public Secondary Schools in Moshi District, Tanzania}

\author{
Mwajuma Bakari Fadhili \\ Teacher, Department of English Language, Kisarika High School, Tanzania
}

\begin{abstract}
:
This study assessed teachers' ability to use English language in giving classroom instructions in Moshi district council. The study was guided by two research questions and one hypothesis. The study aimed at finding: How teachers' use English language to give classroom instructions in secondary schools and extent to which teachers demonstrate ability to maintain using English language to give classroom instructions. The study was guided by social development theory. The sample comprised of 234 respondents whereby 120 were students, 108 teachers and 6 heads of school. Convergent parallel design under mixed approach was employed. Stratified and simple random samplings were used to obtain respondents. Instruments for data collection were questionnaires, observation guide and observation schedule. Quantitative data were analyzed statistically by using frequencies tables and percentages while qualitative data were Transcribed and summarized then narrated. The hypothesis was tested by Chi square at significant level of 0.05. Ethics in writing dissertation were strictly observed. The study found that teachers did not use English properly to give classroom instructions, teachers were not sensitive to note and correct student's English language mistakes. The study concluded that students' poor performance due to poor mastery of English language was due to teachers' inability to note and correct student's language mistakes, therefore the study recommended the government to ensure communication skills course offered in colleges and universities serve the need to equip teachers with English language skills.
\end{abstract}

Keywords: English language and classroom instructions

\section{Background of the Study}

Language serves as a means of social interaction between people allowing the basis of a new and superior form of activity in children, distinguishing them from animals' (Vygotsky, 1978). Qorro (2006) explains that language of instruction is a vehicle through which education is delivered. The role of language of instruction can be likened to that of pipes in carrying water from one destination to another or that of copper wires in transmitting electricity from one station to another. Just as a pipe is an important medium in carrying water, and a copper wire an important medium for transmitting electricity, the language of instruction is an indispensable medium for carrying, or transmitting education from teachers to learners and among learners.

Chapple (2015) found that some of the factors affecting the implementation of English as a medium of instruction are those of linguistic nature. These factors include language of instruction, teachers and learners' prior experiences, their behaviors, attitudes, pedagogical content knowledge, beliefs, personalities as well as cultural values (Nomlomo, 2010). Richard (2017) found that the relationship between the language teachers' proficiency and their ability to teach in the language is complex. Language of instruction is problematic for teachers who recognize limitations in their language abilities as well as for providers of training and professional development programs for teachers. In Ghana, teachers admitted to use Ghanaian language (Fante) most of the time in the classroom instruction instead of English as a medium of instruction due to the claim that learners have low ability in using English language (Owu-Ewie \& Eshun 2015). Teachers play the role of catalysts of learning opportunities which include noticing, uptake, restructuring of the inter-language as well as metacognitive, affective, and other factors that may lead indirectly to language learning' (Anderson, 2015).

In Tanzania, Kiswahili is the national language, language of instruction in public primary schools and English as a subject. But in secondary schools and tertiary education levels, English is the language of instruction and Kiswahili as a subject (URT, 2014). In this case, all teachers except those who specialized in Kiswahili in Tanzania secondary schools must possess English language communication skills like listening, speaking, reading and writing regardless of their subject of specialization. UNICEF (2016) found that majority of the teachers interviewed in the study acknowledged the existence of a language problem in the teaching and learning of science at the secondary level. 


\subsection{Statement of the Problem}

All teachers are ought to use English language to give classroom instructions. However, introduction of English as a medium of instruction in secondary schools has been controversial. It lacks special attention on providing courses in universities and teachers colleges which can equip teachers with language abilities or skills like listening, speaking, reading and writing. Poor performance in 0 -level secondary schools national examinations is claimed to be caused by insufficient English language proficiency: (UNICEF, 2016), (Civan, 2016), Albakri, 2017) and Maganga,(2016).However the studies have insufficiently assessed whether teachers are able to use English language to give classroom instructions to assist students to learn both content and language. Therefore, this study assessed teachers' ability to use English language to give classroom instructions.

\subsection{Research Questions}

The study was guided by the following questions:

- How do teachers use English language to give classroom instructions in secondary schools?

- To what extent do teachers demonstrate ability to maintain using English language to give classroom instructions?

\subsection{Research Hypothesis}

The study tested one hypothesis by using Chi square.

- $\mathrm{H}_{1}$ : There is a significant relationship between teachers' ability to maintain using English language and ability to give classroom instructions.

\subsection{Significance of the Study}

This study's findings revealed useful information to Moshi District Education Officers and other education stakeholders in Tanzania on teachers' ability to give clear classroom instructions by using English language. Since as per education and training policy of 1995 which was revised in 2014 English is the medium of instruction in secondary and tertiary education.

\subsection{Theoretical Framework}

\subsubsection{Social Development Theory (Vygotsky 1978)}

Vygotsky (1978) writes that children solve practical tasks with the help of their speech, as well as their eyes and hands. In Vygotsky's view, speech is an extension of intelligence and thought, a way to interact with one's environment beyond physical limitations. Language serves as a means of social interaction between people, allowing 'the basis of a new and superior form of activity in children, distinguishing them from animals' (Vygotsky, 1978). The more children take advantage of an authority's support, the wider their zone of proximal development and, ultimately, their own capacity. That is intelligence as the capacity to benefit from instruction with language having a powerful developmental roleandin this sense; language is a tool for learning and an aid to understanding. As such, language acts as a vehicle for educational development and is important for acquisition of knowledge whereby basis of education is people interacting with other people.

\subsubsection{Relevance of the Theory to the Study}

The formation of an interactive learning environment in which learning is an ongoing process shared between the teacher and students through language of instruction. Therefore, teachers are ought to be familiar with the language of instruction so as to coach student and assist them to learn. In addition to encourage the development of speech for communication, teachers need to encourage talk which can be exploratory, tentative, used for thinking through problems, for discussing assigned tasks, and for clarifying thought: talk is not merely social and communicative it is also a tool for learning.

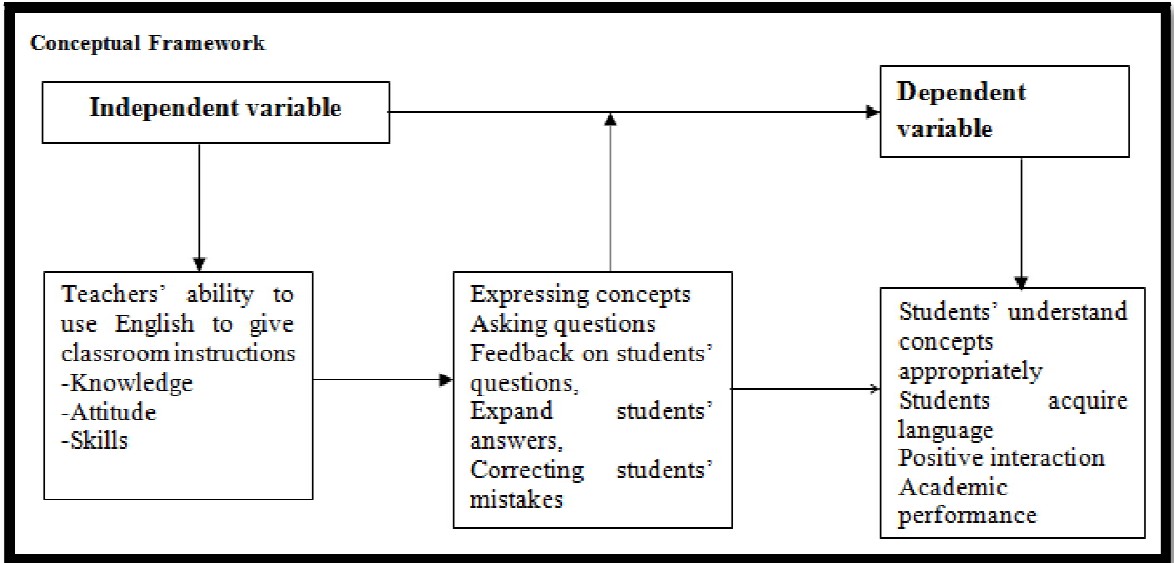

Figure 1: The Conceptual Framework

Source: Modified From Zone of Proximal Development 


\section{Review of Empirical Studies}

\subsection{How Teachers Use English Language to Give Classroom Instructions}

Komba (2015) conducted a study in Tanzania on pupils' language abilities and found that: standard seven pupils could not read books meant for standard two, despite being in English medium schools. Also 50\% of student tested in English language abilities were found to have low proficiency in English language different from expectation of parents. Mariba (2015), conducted study in Tanzania which explored school factors for students' poor performance in form four national examinations in English language. The study found that: discussion debate, question and answer, lecture, role play was the dominant teaching and learning methods, there was a great relationship between teaching and learning environment and students' academic performance in public secondary schools.

Mtallo (2015) conducted a study in Tanzania on teaching and learning English in Tanzania, blessing or curse? The study found that likewise in Vietnam, Tanzania science teachers tend to code-switch when teaching in English, teaching of English focuses on skills than communicative skills for example some students who performed well in examinations but fail to express themselves orally.

\subsection{Maintaining Using English Language to Give Classroom Instructions}

Shen (2014) conducted a study in China on balancing accuracy and fluency in English classroom teaching to improve Chinese non-English majors' oral English ability. Students admitted to have problems in speaking skill and observed teachers used to speak English then translate into Chinese and others spoke too much Chinese in the classroom. Cahn and Renandya (2017) conducted a study in Vietnam on Teachers' proficiency and classroom language use. The study found that teachers' use of English language limited learners' opportunity to learn and little evidence that teachers were aware to teach appropriate communication skills.

The Malaysian English Language Teaching Association (2018) conducted a study in Malaysia about fluency and accuracy in spoken English implication for classroom practice in a bilingual context. The study found that $92 \%$ of the respondents use both English and Bahasa Malaysia to give instruction, peer interaction is almost entirely in the mother tongue. The study population was both teachers and students but finding presented in detail about students' failure to master English in the classroom.

\section{Research Designs}

This study employed convergent parallel design under mixed approach. Convergent parallel design allowed the researcher to collect both quantitative and qualitative data, analyzed them separately and then compared results if they confirmed or disconfirmed each other.

\subsection{Target Population}

The target population in this study was all 56 0-level public secondary schools in Moshi District, 56 heads of school, 1105 O-level teachers, and 24894 students.

\subsection{Description of Sample and Sampling Procedures}

The study employed both probability and non-probability sampling techniques for selecting respondents. The sample frame was as summarized in table 1.

\begin{tabular}{|c|c|c|c|}
\hline Category of Population & $\begin{array}{c}\text { Total Number of } \\
\text { Population }\end{array}$ & $\begin{array}{c}\text { Number of } \\
\text { Respondents }\end{array}$ & Sampling Techniques \\
\hline Schools & 56 & 06 & Simple random \\
\hline Teachers & 1105 & 108 & Stratified/simple random \\
\hline Students & 24894 & 120 & Stratified/simple random \\
\hline Heads of schools & 56 & 06 & No sampling \\
\hline Total number of respondents & 234 & & \\
\hline
\end{tabular}

Table 1: Sampling Matrixes Present the Sampling Frame

Source Field, 2019

\subsection{Description of Data Collection Instruments}

Data collection methods used in the study were: questionnaires, observational schedule and observation guides. Observation guide and schedule were used to collect information in the classrooms on how teachers use English language to give classroom instructions and whether teachers are able to maintain using English language when giving classroom instructions.

\subsection{Validity of the Research Instruments}

Validity of instruments was be ensured by taking them to two research experts in the Faculty of Education from Mwenge Catholic University. These experts are knowledgeable enough in the field of research to check ambiguous, clarity, spellings of the language. Necessary changes were done to ensure usefulness of instruments to collect intended data. The validity in data collection ensured by using two techniques, first the use of triangulation technique and second pilot study were conducted. Triangulation refers to the use of multiple data collection methods so as to ensure the correctness of the findings by comparing the data from different sources. 


\subsection{Pilot Testing of the Research Instruments}

Pilot study was carried out in two secondary schools as a sample in order to insure validity and reliability of the instruments before collection. Schools involved in pilot were not included in data collection. Results from piloting helped the researcher to correct the instruments with ambiguity, unclear language; unnecessary words and irrelevant question items were removed to reconstruct instruments.

\subsection{Reliability of the Research Instruments}

In quantitative data from students', teachers and heads of school questionnaires, Cronbach Alpha was used to measure the reliability or the internal consistency of the Likert type instruments. Whereby reliability for heads of school questionnaires was 0.78 , reliability for teachers' questionnaires was 0.81 and reliability for students was 0.79 . To triangulate the researcher used multiple data sources in conducting the study for proper understanding for example teachers, heads of schools and students were included in the study, questionnaires and observation were used to collect data.

\section{Data Presentation, Interpretation and Discussion}

\subsection{How Teachers Use English Language to Give Classroom Instructions}

\begin{tabular}{|c|c|c|c|c|c|}
\hline \multirow{2}{*}{$\begin{array}{l}\text { How teachers Use English Language to Give } \\
\text { Classroom Instructions }\end{array}$} & $\mathbf{P}$ & $\mathbf{F}$ & G & VG & $\mathbf{E}$ \\
\hline & f (\%) & f (\%) & f (\%) & f (\%) & f (\%) \\
\hline $\begin{array}{l}\text { 1. Ability to express concepts in correct } \\
\text { English }\end{array}$ & - & $5(83.33)$ & - & $1(16.66)$ & - \\
\hline 2. Ability to ask questions in correct English & - & $4(66.66)$ & - & $2(33.34)$ & - \\
\hline 3. Ability to give feedback in correct English & - & $5(83.3)$ & - & - & $1(16.7)$ \\
\hline $\begin{array}{l}\text { 4. Ability to summarize lesson on the board } \\
\text { in correct English }\end{array}$ & - & - & $6(100)$ & - & - \\
\hline $\begin{array}{l}\text { 5. Ability to give appropriate examples in } \\
\text { correct English }\end{array}$ & - & $4(66.7)$ & - & $2(33.3)$ & - \\
\hline $\begin{array}{l}\text { 6. Ability to expand students' responses in } \\
\text { correct English }\end{array}$ & $2(33)$ & $4(66.7)$ & - & - & - \\
\hline $\begin{array}{l}\text { 7. Ability to summarize lesson orally in } \\
\text { correct English }\end{array}$ & - & $5(83.3)$ & - & $1(16.7)$ & - \\
\hline $\begin{array}{l}\text { 8. Ability to use English to manage } \\
\text { classroom }\end{array}$ & - & 3() & 1() & 1() & - \\
\hline $\begin{array}{ll}\text { 9. Ability to correct student's English } \\
\text { language mistakes in the classroom }\end{array}$ & - & $3(50)$ & $3(50)$ & - & - \\
\hline $\begin{array}{l}\text { 10. Ability to organize class activities in } \\
\text { correct English }\end{array}$ & - & $4(66.7)$ & - & $2(33.3)$ & - \\
\hline
\end{tabular}

Table 2: Heads of Schools' Responses on How Teachers Use English Language to Give Classroom Instructions Source: Field Data, 2019

Key: E=Excellent, $V G=$ Very Good, $G=$ Good, $F=$ Fair and $P=$ Poor

Ability to express concepts in correct English in the classroom 5 (83.33\%) heads of schools indicated fairly. Expressing concept in correct English, teachers' demonstrations and explanations of concepts serves as environmental input for students (Chunk, 2012). Thus, students have to learn good language from teachers as inputs; therefore, teachers in ability to express concepts well in English hinder students' proper learning of English. Also heads of schools indicated that most of (66.66\%) teachers do not ask questions properly in English language, apart from that, heads of school rated teachers' ability to give feedback in correct English as 5(83.3\%) fair. These were also observed by Day and Thao (2017) found that teachers do not mark student's English language errors in the classroom to assist students improve their language. Moreover, most of teachers $4(66.7 \%)$ are not able to give examples from the environment in English language and therefore they do not assist students to improve or add their vocabularies, 4(66.7\%) fair. teachers do not add knowledge on what students know which could together help students to improve their language by imitating teachers' vocabularies, tense, pronunciation. Besides, heads of school rated teachers' ability to summarize lessons orally in English as: $5(83.3 \%)$ fair. This implies teachers do not summarize lessons orally in the classroom which could assist students to improve their speaking skills. Also, ability of teachers to manage classroom in English was rated by heads of schools as: $3(50 \%)$ fair. This shows that as per heads of school's observation teachers use other language to manage classrooms rather than English language to enhance students to learn language especially vocabularies according to context. Moreover, heads of school indicated how teachers correct students' language mistakes in the classroom as: $5(50 \%)$ fair and $5(50 \%)$ good. In addition to that, heads of schools indicated as follows on teachers' ability to organize class activities in correct English: 4(66.7\%) fair and 2(33.3\%) very good. These results indicate that teachers are not able to organize classroom activities like discussions, presentations in English language which could help students to learn vocabularies and other language skills from teachers. 


\begin{tabular}{|c|c|c|c|c|c|}
\hline & $\mathbf{P}$ & $\mathbf{F}$ & $\mathbf{G}$ & VG & $\mathbf{E}$ \\
\hline & $\mathrm{f}(\%)$ & f (\%) & $f(\%)$ & f (\%) & $f(\%)$ \\
\hline 1. Ability to express concepts in correct English & - & $3(2.8)$ & $20(18.5)$ & $50(46.3)$ & $35(32.4)$ \\
\hline 2. Ability to ask questions in correct English & - & $3(3)$ & $23(21)$ & $50(46)$ & $32(30)$ \\
\hline 3. Ability to give feedback in correct English & - & $7(6)$ & $30(28)$ & $70(65)$ & $1(1)$ \\
\hline $\begin{array}{l}\text { 4. Ability to summarize lesson on the board in } \\
\text { correct English }\end{array}$ & $4(4)$ & $6(6)$ & $20(19)$ & 40 (37) & $38(35)$ \\
\hline $\begin{array}{l}\text { 5. Ability to give appropriate examples in correct } \\
\text { English }\end{array}$ & - & $8(7)$ & $10(9)$ & $60(56)$ & $30(28)$ \\
\hline $\begin{array}{l}\text { 6. Ability to expand students' responses in correct } \\
\text { English }\end{array}$ & - & $7(6)$ & $20(19)$ & $70(65)$ & $11(10)$ \\
\hline $\begin{array}{l}\text { 7. Ability to summarize lesson orally in correct } \\
\text { English }\end{array}$ & $3(3)$ & $3(3)$ & $13(12)$ & $58(54)$ & $34(31)$ \\
\hline 8. Ability to use English to manage classroom & - & $7(6)$ & $29(27)$ & $52(48)$ & $20(19)$ \\
\hline $\begin{array}{l}\text { 9. Ability to correct student's English language } \\
\text { mistakes in the classroom }\end{array}$ & - & $10(9.3)$ & $37(34.3)$ & $40(37)$ & $21(19.4)$ \\
\hline $\begin{array}{l}\text { 10. Ability to organize class activities in correct } \\
\text { English }\end{array}$ & $3(3)$ & - & $30(28)$ & $5(5)$ & $25(23)$ \\
\hline
\end{tabular}

Table 3: Teachers' Responses on How They Use English Language to Give Classroom Instructions Source: Field Data, 2019

Key: $E=$ Excellent, $V G=$ Very Good, $G=$ Good, $F=$ Fair and $P=P$ Poor

Data in Table 3 indicate responses from teachers on how they use English language to give classroom instructions. Most of teachers about 76\% indicated that they are very good in using English language to express concepts in the classroom. About 75\% of teachers claim to use correct English language to ask students questions in the classroom. Apart from that about $66 \%$ teachers rated they to give feedback on students' questions in the classroom therefore students had to learn the language properly from them. On the other hand, on whether teachers summarize lessons on the board in correct English most of teachers $72 \%$ rated very good and excellence.

Likewise, in giving appropriate examples in English teachers indicated: 8(7\%) fair, 10(9\%) good, 60(56\%) very good and 30(28\%) excellent. This implies that most of teachers about $90 \%$ claim to give appropriate example in English. Likewise, on whether teachers expand students' knowledge in correct English language, teachers' responses were: 7(6\%) fair, 20(19\%) good, 70(65\%) very good and 11(10\%) excellent. That is about 75\% indicated to expand students' response in English language which assists students to learn language as well as content. Furthermore, teachers' responses on whether they summarize lessons orally in English were: 3(3\%) poor, 3(3\%) fair, 13(12\%) good, 58(54\%) very good and $34(31 \%)$ excellent. This means that most of teachers about $85 \%$ summarize lessons orally by using English language in the classroom. On the other hand, teachers indicated their ability to manage classroom in English language as: $7(6 \%)$ fair, $29(27 \%)$ good, $52(48 \%)$ very good and 20(19\%) excellent. Thus, most of the teachers about $67 \%$ indicated to manage classroom in English language to enhance students learn English language. In the same way about 56\% of teachers indicated to correct students' English language in the classroom to help students to learn English language parallel with content. But about $44 \%$ of teachers indicated that they do not correct students' language mistakes properly. In addition to that, teachers indicated on how they use English language to organize class activities as follows: $3(2.8 \%)$ poor, $30(28 \%)$ good, $5(5 \%)$ very good and $25(23 \%)$ excellent. teachers indicated to organize class activities in English language.

\begin{tabular}{|c|c|c|c|c|c|}
\hline \multirow{2}{*}{$\begin{array}{c}\text { How Teachers Use English Language to Give } \\
\text { Classroom Instructions }\end{array}$} & $\mathbf{P}$ & $\mathbf{F}$ & $\mathbf{G}$ & VG & $\mathbf{E}$ \\
\hline & $f(\%)$ & f (\%) & $f(\%)$ & f (\%) & $f(\%)$ \\
\hline $\begin{array}{l}\text { 1. Teachers use English to express concepts } \\
\text { in the classroom }\end{array}$ & $14(12)$ & $48(40)$ & $8(7)$ & $32(27)$ & $18(15)$ \\
\hline $\begin{array}{l}\text { 2. Teachers use English to ask questions in } \\
\text { the classroom }\end{array}$ & $32(27)$ & $41(34)$ & $3(3)$ & $36(30)$ & $8(7)$ \\
\hline $\begin{array}{l}\text { 3. Teachers use correct English to give } \\
\text { feedback on questions in the classroom }\end{array}$ & $40(33.33)$ & $30(25)$ & $34(28.33)$ & $12(10)$ & $4(3)$ \\
\hline $\begin{array}{llll}\text { 4. Teachers use correct } & \text { English } & \text { to } \\
\text { summarize lessons orally } & & \\
\end{array}$ & $21(18)$ & $39(33)$ & $16(13)$ & $22(18)$ & $22(18)$ \\
\hline $\begin{array}{l}\text { 5. Teachers give appropriate examples in } \\
\text { English }\end{array}$ & $37(31)$ & $19(16)$ & $31(26)$ & $23(19)$ & $10(8)$ \\
\hline $\begin{array}{l}\text { 6. Teachers expand students' responses in } \\
\text { English }\end{array}$ & $20(17)$ & $49(40.83)$ & $17(14)$ & $23(19)$ & $11(9)$ \\
\hline 7. Teachers summarize lessons in English & $31(26)$ & $35(29)$ & $16(13)$ & $17(14)$ & 21(18) \\
\hline $\begin{array}{l}\text { 8. Teachers use English to give orders, } \\
\text { directives in the classroom }\end{array}$ & $33(28)$ & $30(25)$ & $13(11)$ & $22(18)$ & $22(18)$ \\
\hline $\begin{array}{l}\text { 9. Teachers correct student's language } \\
\text { mistake in English }\end{array}$ & $35(29.16)$ & $40(33.33)$ & $15(12.5)$ & $20(16.66)$ & $10(8.3)$ \\
\hline $\begin{array}{l}\text { 10. Teacher organize class activities in } \\
\text { English }\end{array}$ & $31(26)$ & $31(26)$ & $26(22)$ & $15(13)$ & $17(14)$ \\
\hline
\end{tabular}

Table 4: Students' Responses on How Teachers Use English Language to Give Classroom 
On whether teachers use English language to give classroom instruction about $52 \%$ of students indicated that teachers do not express concepts properly in English. Likewise, students indicated that about $61 \%$ of teachers do not use English language to ask questions; about 58\% do not use correct English to give feedback on students' questions in the classrooms which implies that students' language mistakes are due to teachers' lack of knowledge to correct their mistakes. Vygotsky (1978) explains that authority or teacher acts as collaborator and coach. Thus, students' poor language is affected by teachers' failure to give appropriate feedback on their language. Moreover students indicated that: most of the teachers about $51 \%$ do not summarize lessons orally by using correct English language, 55\% of teachers do not expand students responses in English language, 53\% they poorly give orders and directives in English language, 62\% do not correct students English language mistakes and most of teachers about $52 \%$ do not organize class activities in English language.

\subsection{Extent to Which Teachers Demonstrate Ability to Maintain Using English Language Accurately in the Classroom}

\begin{tabular}{|c|c|c|c|c|c|}
\hline & $\mathbf{N}$ & $\mathbf{R}$ & $\mathbf{S}$ & $\mathbf{0}$ & $\mathbf{A}$ \\
\hline Teachers ability to maintain using English & f (\%) & f (\%) & f (\%) & f (\%) & f (\%) \\
\hline $\begin{array}{l}\text { 1. Teachers code mix in the classroom } \\
\text { due to request from students }\end{array}$ & - & - & - & $6(100)$ & - \\
\hline $\begin{array}{l}\text { 2. } \begin{array}{l}\text { Teachers code switch in the } \\
\text { classroom due to request from } \\
\text { students }\end{array} \\
\end{array}$ & - & - & - & $4(66.7)$ & $2(33.3)$ \\
\hline $\begin{array}{l}\text { 3. Teachers use English then translate to } \\
\text { Kiswahili }\end{array}$ & - & - & 1 (16.7) & $3(50)$ & $2(33.3)$ \\
\hline $\begin{array}{l}\text { 4. Teachers use appropriate English } \\
\text { throughout the lesson }\end{array}$ & - & $3(50)$ & 1 (16.7) & $2(33.3)$ & - \\
\hline 5. Teachers monitor'students' activities & - & $4(66.7)$ & $2(33.3)$ & - & - \\
\hline 6. Teachers pronounce words properly & - & $4(66.7)$ & $2(33.3)$ & - & - \\
\hline $\begin{array}{l}\text { 7. Teachers confident to give classroom } \\
\text { instruction in English }\end{array}$ & - & - & $4(66.7)$ & $2(33.3)$ & - \\
\hline $\begin{array}{l}\text { 8. Teachers write words properly on the } \\
\text { board }\end{array}$ & - & - & $2(33.3)$ & $2(33.3)$ & $2(33.3)$ \\
\hline 9. Teachers repeat words unnecessarily & - & - & 5 (83.3) & 1 (16.7) & - \\
\hline
\end{tabular}

Table 5: Heads of School Responses on the Extent to Which Teachers Demonstrate Ability to Maintain Using English Language Accurately in the Classroom

Source: Field Data, 2019

Key: $A=$ =Always, $O=O f t e n, S=$ Sometimes, $R=$ Rarely, $N=$ Never

Results in Table 5 show that $6(100 \%)$ of heads of schools indicated that teachers code mix in the classroom without request from students. Also heads of school 2(33.3\%) indicated that teachers always shift from English to other languages, 4(66.7\%) indicated that teachers often shift from English to other languages in the classroom. These indicates that teachers are not able to maintain using English in the classroom. Whether teachers using English then translate to Kiswahili was indicated by heads of schools as: 2(33.3\%) always, 3(50\%) often, 1(16.7\%) sometimes. This indicates that teachers translate concepts from English to Kiswahili instead of clarifying in English. Also, on whether teachers use correct English throughout the lesson was indicated by heads of schools as: $3(50 \%)$ rarely, 2(33.3\%) always, and 1(16.66\%) sometimes. This implies about 50\% of teachers do not use correct English throughout the lesson which means it hinders students to learn the language in the classroom. On whether teachers pronounce English language words properly, the heads of schools responded: $4(66.7 \%)$ rarely, 2(33.3\%) sometimes. This shows that teachers are not able to pronounce English language words in the classroom and therefore students cannot learn pronunciation well from their teachers. Likewise, heads of schools indicated whether teachers write words properly on the board as: $2(33.3 \%)$ always, $2(33.33 \%)$ often and $2(33.3 \%)$ sometimes. These means about $66 \%$ of teachers write words properly on the boards. Heads of school's responses on whether teachers monitor students' activities in English were: 4(66.7\%) rarely, 2(33.3\%) sometimes. These findings imply that about $66 \%$ of teachers do not use English language when monitoring students' activities in the classroom. Also heads of schools indicated on whether teachers are confident to give classroom instructions in English as: $4(66.7 \%)$ sometimes and $2(33.3 \%)$ often. These indicates that most of the teachers are not confident enough when giving classroom instructions in English Lastly, most of the heads of schools 5(83.3\% indicated that teacher sometimes repeat words unnecessarily in the classroom this may be due to lack of vocabularies.

Also 108 teachers were provided with questionnaires to indicate whether they maintain using English language in the classroom and results were as summarized in Table 6. 


\begin{tabular}{|c|c|c|c|c|c|}
\hline \multirow{2}{*}{$\begin{array}{c}\text { Teachers' to Maintain Using English Language } \\
\text { in the Classroom }\end{array}$} & $\mathbf{N}$ & $\mathbf{R}$ & $\mathbf{S}$ & $\mathbf{0}$ & $\mathbf{A}$ \\
\hline & f (\%) & f (\%) & f (\%) & $f(\%)$ & $f(\%)$ \\
\hline I code mix in the classroom & $4(3)$ & $23(19)$ & $30(31)$ & $33(32)$ & $18(15)$ \\
\hline I code switch in the classroom & $8(7)$ & $40(35)$ & $18(15)$ & $31(34)$ & $11(9)$ \\
\hline I use English then translate to Kiswahili & $28(23)$ & $10(13)$ & $50(48)$ & $17(14)$ & $3(3)$ \\
\hline I use English throughout the lesson & $4(3)$ & $13(11)$ & $27(23)$ & $34(37)$ & $30(27)$ \\
\hline $\begin{array}{l}5 . \quad \text { I monitor students' activities in English } \\
\text { in the classroom }\end{array}$ & - & $3(3)$ & $15(15)$ & $40(38)$ & $50(44)$ \\
\hline $\begin{array}{l}\text { 6. I pronounce words properly in the } \\
\text { classroom }\end{array}$ & - & - & $4(3)$ & $44(43)$ & $60(54)$ \\
\hline $\begin{array}{l}\text { 7. I am confident to give classroom } \\
\text { instruction in English }\end{array}$ & - & - & $3(2.8)$ & $35(32.4)$ & $70(64.8)$ \\
\hline 8. I write words properly on the board & - & $4(3)$ & $3(3)$ & $29(24)$ & $84(70)$ \\
\hline $\begin{array}{l}\text { 9. I repeat words unnecessarily in the } \\
\text { classroom }\end{array}$ & $18(15)$ & $26(22)$ & $30(33)$ & $27(23)$ & $7(8)$ \\
\hline
\end{tabular}

Table 6: Teachers Responses on the Extent to Which They Demonstrate Ability to Maintain Using English Language Accurately in the Classroom Source: Field Data, 2019

Key: $A=$ Always, $O=O f t e n, S=S o m e t i m e s, R=$ Rarely, $N=$ Never

On code mixing in the classroom about $47 \%$ of teachers admitted to mix languages in the classroom which means they do not maintain using English language throughout the lessons. Whether teachers code from English to other languages teachers responded: 8(7\%) never, $40(35 \%)$ rarely, 31(34\%) often and 11(9\%) always. These findings imply that most of the teachers switch from English to other languages in the classroom. Also, on using English then translation to Kiswahili few teachers about 17\% translate from English to Kiswahili. However, most of teachers 64\% indicated to use English language throughout in the classroom despite their agreement that they mix languages, shift from English to Kiswahili. Also, most of teachers 50(44\%) indicated they always monitor students' activities in English in the classroom. This means teachers claim to monitor class activities in English.

Besides, teachers had to indicate whether they pronounce English language words properly in the classroom and results were: $60(54 \%)$ always, $44(43 \%)$ often and $4(3 \%)$ sometimes. According to these findings' teachers claim to pronounce words properly in the classroom. Teachers indicated their confidence when giving classroom instructions in English as: $70(64.8 \%)$ always, $35(32.4 \%)$ often and 3(2.8\%) sometimes. This implies that most of the teachers $97 \%$ are confident when giving classroom instruction in English. Apart from that, teachers' responses on whether they write words properly on the boards were: $84(70 \%)$ always, $29(24 \%)$ often, $3(2.8 \%)$ sometimes and $4(3 \%)$ rarely. Most of the teachers $94 \%$ write words properly on the boards which allow students to learn how to spell English language words. However, teachers' responses on whether they repeat words unnecessarily in the classrooms were: $7(8 \%)$ always, $27(23 \%)$ often, $30(33 \%)$ sometimes, $26(22 \% 0$ rarely and $18(15 \%)$ never. These findings imply that teachers rated themselves to have varying vocabularies in the classroom. Students were provided with the same questionnaires to confirm if teachers maintained using English language when giving classroom instructions and results were as summarized in Table 7.

\begin{tabular}{|c|c|c|c|c|c|}
\hline & $\mathbf{N}$ & $\mathbf{R}$ & S & 0 & $\mathbf{A}$ \\
\hline $\begin{array}{c}\text { Teacher maintain Using English Language } \\
\text { Accurately in the Classroom }\end{array}$ & f (\%) & $f(\%)$ & $f(\%)$ & $f(\%)$ & $f(\%)$ \\
\hline $\begin{array}{l}\text { 1. Teachers use English, Kiswahili and } \\
\text { other languages in the classroom }\end{array}$ & $10(8)$ & $17(14)$ & $18(15)$ & $56(47)$ & 19(16) \\
\hline $\begin{array}{l}\text { 2. Teachers switch from English to } \\
\text { Kiswahili in the classroom }\end{array}$ & $10(8)$ & $8(7)$ & $24(20)$ & $61(52)$ & $17(14)$ \\
\hline $\begin{array}{l}\text { 3. Teachers use English then translate to } \\
\text { Kiswahili }\end{array}$ & $6(5)$ & $23(19)$ & $37(31)$ & $21(18)$ & $33(28)$ \\
\hline $\begin{array}{l}\text { 4. Teachers use English throughout the } \\
\text { lesson }\end{array}$ & $26(22)$ & 20(17) & $46(38)$ & $14(12)$ & $14(12)$ \\
\hline $\begin{array}{l}\text { 5. Teachers give accurate explanations } \\
\text { in English }\end{array}$ & $9(8)$ & $20(17)$ & $44(37)$ & $20(17)$ & $27(23)$ \\
\hline 6. Teachers pronounce words properly & 11(9) & 19(16) & $39(33)$ & $27(23)$ & $24(20)$ \\
\hline $\begin{array}{l}\text { 7. Teachers' are confident to give } \\
\text { classroom instruction in English }\end{array}$ & $4(3)$ & 11(9) & $34(28)$ & $23(19)$ & $48(40)$ \\
\hline $\begin{array}{l}\text { 8. Teachers guide discussions, } \\
\text { presentations and class activities in } \\
\text { English } \\
\end{array}$ & $20(16.7)$ & $53(44.2)$ & $30(25)$ & $4(3.3)$ & $13(10.8)$ \\
\hline $\begin{array}{l}\text { 9. Teachers write words properly on the } \\
\text { board }\end{array}$ & $10(8)$ & $6(5)$ & $20(17)$ & $31(26)$ & $53(44)$ \\
\hline
\end{tabular}

Table 7: Students Responses on the Extent to Which Teachers Demonstrate Ability to Maintain Using English Language Accurately in the Classroom

Source: Field Data, 2019

Key: A=Always, $O=O f t e n, S=$ Sometimes, $R=$ Rarely, $N=$ Never 
Students were provided with questionnaires to give information about teachers if they maintain using English language when giving classroom instructions. Students responses on whether teachers mix languages like English and Kiswahili in the classroom were: $10(8 \%)$ never, $17(14 \%)$ rarely, $18(15 \%)$ sometimes, $56(47 \%)$ often and $19(16 \%)$ always. This was also observed in Malaysia by the Malaysian English Language Association (2018) that most of the teachers used both English and Bahasa to give classroom instructions which implies that teachers mix languages in the classroom instead of using English language throughout. Whether teachers switch from English to Kiswahili students responded: $10(8 \%)$ never, $8(7 \%)$ rarely, $24(20 \%)$ sometimes, $61(52 \%)$ often and $17(14 \%)$ always. Most of the teachers seem to fail using English language hence shifted to Kiswahili which they master more than English. Similarly, on teachers using English then translate to Kiswahili, students responded: 4(5\%) never, 23(19\%) rarely, 37(31\%) sometimes, $21(18 \%)$, often and 33(28\%) always. These responses show that teachers kept on translating concepts in the classroom from English to Kiswahili instead of explaining in English language to help students to learn the language. Also, students indicated that $26(22 \%)$ never, $20(17 \%)$ rarely, $46(38 \%)$ sometimes, $14(12 \% 0$ often and $14(12 \%)$ always use English throughout in the classrooms. Few teachers use English language throughout the lesson in the classroom. This resembles responses in teachers mix languages and switch from English to Kiswahili, which therefore implies that teachers are not able to maintain using English language to give classroom instructions.

Furthermore, students indicated if teachers give accurate explanations in English as: 9(8\%) never, 20(17\%) rarely, $44(37 \%)$ sometimes, $20(17 \%)$ often and $27(23 \%)$ always. These responses show that few teachers $40 \%$ give accurate explanations in English which in turn means teachers are not able to explain different concepts in English when giving classroom instructions. Students were also asked on if teachers pronounce English language word properly whereby responses were: 11(9\%) never, 19(16\%) rarely, 39(33\%) sometimes, 27(23\%) often and 24(20\%) always. Students declared few teachers $43 \%$ to pronounce words properly, although students may not be able to note all pronunciation errors. Most of teachers 59\% were indicated by students to be confident when giving classroom instruction in English. Then again, students' responses on if teacher's guide discussions, presentations and class activities in English language were: $20(16.66 \%)$ never, 53(44.16\%) rarely, 30(25\%) sometimes, $4(3.33 \%)$ often and $13(10.83 \%)$ always. Due to students' responses teachers do not maintain using English language since discussions, presentations and other classrooms activities are not always guided in English language. This hinders students from practicing and learning English language. Apart from that, teachers' ability to write words properly on the board was indicated by students as follows: $10(8 \%)$ never, $6(5 \%)$ rarely, $20(17 \%)$ sometimes $31(26 \%)$ often and 53(44\%) always. These findings from students are consistent with data from heads of schools and teachers themselves that they write words properly on the boards. AlHassan (2017) found that most of the teachers were able to write words properly on classroom boards which means that teachers are able to write English language words properly.

\begin{tabular}{|c|c|c|c|}
\hline \multicolumn{2}{|r|}{ Teacher maintain Using English Language Accurately in the Classroom } & Yes & No \\
\hline & & $\mathrm{f}(\%)$ & $\mathrm{f}(\%)$ \\
\hline 1. & 1. Teacher code mixes in the classroom & $15(83.3)$ & $3(16.7)$ \\
\hline 2. & 2. Teacher Code switches in the classroom & $14(77.8)$ & $4(22.2)$ \\
\hline 3. & 3. Teacher uses English then translate to Kiswahili & $16(88.9)$ & $2(11.1)$ \\
\hline 4. & 4. Teacher uses accurate English throughout the lesson & $3(16.7)$ & $15(83.3)$ \\
\hline 5. & 5. Teacher Monitors students' activities in correct English & $10(55.6)$ & $8(44.4)$ \\
\hline 6. & 6. Teacher pronounces words properly & $4(22.2)$ & $14(77.8)$ \\
\hline 7. & 7. Teacher is confident to give classroom instructions in English & $17(94.4)$ & $(5.5)$ \\
\hline 8. & 8. Teacher writes words properly on the board & $15(83.3)$ & $3(16.7)$ \\
\hline 9. & 9. Teacher repeats words unnecessarily in the classroom & $14(77.8)$ & $4(22.2)$ \\
\hline
\end{tabular}

Table 8: Classroom Observation Schedule on the Extent to Which Teachers

Demonstrate Ability to Maintain Using English Language Accurately in the Classroom

Source: Field Data, 2019

Keys: F= Frequency, \% Percentage

Findings in Table 7 indicate that: 83.3\% of the teacher's code mix English language and Kiswahili in classrooms without request from students. Elibariki (2017) observed that most of primary schools' teachers fail to use English language throughout in classrooms. Also, most of the teachers 77.8\% switched from English to Kiswahili when explaining some concepts in the classroom, 88.9\% of teachers translated concepts from English to Kiswahili instead of explaining. These findings are in agreement with Shen (2014) who found that teachers translated concepts from English to Chinese instead of explaining. Furthermore, most of teachers $83.3 \%$ were noted with serious problems in tense, articles, pronouns, singular and plurals in nouns. When monitoring students' activities in the classrooms like discussions, presentations most of teachers 55.6\% used English although with a lot of errors. Most $77.8 \%$ of the teachers did not pronounce words properly in the classroom to enhance students to learn pronouncing English language words. Furthermore, teachers were confident $94.4 \%$ when fiving classroom instructions in English language regardless of incorrectness of the English language they used. Most of the teachers 83.3\% wrote words properly on the boards since they were copying from their notes. Most of the observed teachers $14(77 \%)$ repeated words in the classroom unnecessarily when giving classroom instruction due to lack of vocabularies whereby students can hardly improve their vocabularies. These findings from classrooms observation revealed that most of the teachers were not able to maintain using correct English language when giving classrooms instructions. These findings are in agreement with Cahn and Renandya (2017) observed that teachers 
use of English language limited learners to learn and teachers were found to fail teaching inappropriate communications skills.

\section{Summary of the Findings}

\subsection{Teachers Ability to Use English Language to Give Classroom Instructions in Secondary Schools}

Findings from how teachers use English language revealed that: Teachers do not express concepts in the classrooms by using correct English, teachers do not ask questions and give feedback in correct English in classrooms. Also, teachers were found to ignore students' English language mistakes and concentrated on subjects' content, students' knowledge were not expanded in English to allow them to learn English. Furthermore, most of classroom activities were not organized in English language for students to practice using English language, teachers were confident to give classroom instructions in English. Similarly, teachers did not summarize lessons well orally to enhance students to develop speaking skills.

\subsection{Teachers Ability to Demonstrate Ability to Maintain Using English Language to Give Classroom Instructions}

Results from extent to which teachers demonstrate ability to maintain using English language in the classrooms revealed that: Teachers code mix and switch without request from students which mean they lack enough vocabularies. Instead of explaining or clarifying concepts more in English teachers were translating from English to Kiswahili, teachers do not pronounce words properly. Students' activities were not monitored in English all the time, teachers were confident when giving classroom instructions, most of teachers wrote words properly on the boards.

That not only students who claimed to have problems in using English even teachers cannot maintain using English throughout the lessons.

\subsection{Findings from the Hypothesis Tested}

Findings revealed that there is a significant relationship between teachers' ability to maintain using English language and ability to give classroom instructions. This means since teachers are supposed to use English language to give classroom instructions, their ability to maintain using English language affects ability to give classroom instructions. This is because concepts are to be clarified in English so failure to use the language results to improper delivery of the lessons.

\subsection{Conclusions of the Study}

On the basis of the findings, the following conclusions were made:

Most of teachers who are to facilitate learning of contents and English language are not able to use English language well to give classroom instructions. Also, teachers do not maintain using English language when giving classroom instructions and ignore student's English language mistakes

\subsection{Recommendations}

Due to findings, discussion and conclusions, this study recommends the following that will be beneficial to the educational stakeholders like heads of schools, teachers, parents/guardians, students, and the government:

- The government under TCU should ensure that universities offer communication skills course with appropriate units and enough time which will assist teacher trainees to possess basic English language skills

- Also, for students to learn contents parallel with English language, teacher must correct students' English mistakes in classroom regardless of their subjects

- The government should not rely on subjects' performance only as criteria for secondary schools' teachers to be rather ability to listen, speak, read and write in English to be of major criteria.

- For better teaching and learning teachers should practice using English language frequently

\section{References}

i. Albakri, S. (2017). Effects of English Medium of Instruction on Students' Learning Experience and Quality Education. Oman.

ii. AlHassan, Anka. S. M \& Yabo. N. U. (2017). English as Medium of Instructions: Challenge to Nigerian Primary Schools. Nigeria.

iii. Anderson, J. (2015) Affordance, learning opportunities, and the lesson plan pro forma.

iv. Boston University School of Public Health, (2013). The Social Cognitive Theory. Retrieved from: http://sph.bu.edu/otlt/MPH-Modules/SB/SB721-Models/SB721-Models5.html

v. Cahn, V.L. \& Renandya. A. W. (2017). Teachers' English Proficiency and Classroom Language. Singapore.

vi. Chapple, J. (2015).Teaching English is not necessary the teaching of English. Japan

vii. Chunk, D.H. (2012).Learning Theories: An Educational Perspective.(6 ${ }^{\text {th }}$ Ed). Baston: Pearson Education, Inc.

viii. Civan A, (2016). Effects of Medium Of Instruction Language On Academic Success. Turkey.

ix. Creswell, J.W, (2012).Educational Research: Planning, conducting and Evaluating Quantitative and Qualitative Research (4thed.). Boston, USA

x. Creswell, J.W, (2014).Research Designs: Quantitative, Qualitative and Mixed Method Approach.(4thed.).Boston, USA. 
xi. Creswell,J.W. (2007). Qualitative inquiry and research design: Choosing among five approaches (2nded.).Thousand Oasks, CA: Sage

xii. Elibariki, M. (2017).Challenges facing primary schools pupils in learning English as a foreign language. Tanzania. ELT Journal

xiii. Israel, M. \&Hay, l. (2006). Research ethics for social scientists: Between ethical conduct and regulatory compliance. London: Sage.

xiv. Kinyaduka, D.B. (2013).Language of Instruction and its Impact on Quality of Education in Secondary Schools. Tanzania.

xv. Komba, C.S.(2015).Pupils' Language Abilities In Tanzania. Tanzania.

xvi. Maganga, J.H. (2016).Factors Affecting Students Performance: A case Study in DarEs Salaam. Tanzania.

xvii. Mariba, M.M.(2015).Schools' factors for academic poor performance in form four national examinations. Tanzania.

xviii. Mtallo, R.G.(2015). Teaching and learning English in Tanzania a blessing or Curse. Tanzania.

xix. Mugenda, O. \& Mugenda, A, (2003). Research methods. Quantitative and Qualitative Approaches. African Centre for Technology Studies. Nairobi.

xx. Nomlomo, V. (2010).Classroom Interaction: Turn-Talking as a Pedagogical Strategy. Journal of Language Learning.Vol 26(2):50-66, University of West Cape

xxi. Owu.E.C\&Eshun.R.S. (2015). The use of English as a Medium of Instruction at the Upper Basic Level. Ghana.

xxii. Qorro, M. (2006).Does Language of Instruction affects Quality of Education: HAKIELIMU. Tanzania

xxiii. Richard, C.J (2017).Teaching English Through English. Singapore

xxiv. Education,2(3),25-35.

xxv. Shen, Y. (2014).Balancing Accuracy and Fluency in English Classroom Teaching to Improve Chinese Non

xxvi. The Malaysian English Language Teaching Association,(2018).Fluency in Spoken English: Implication for Classroom Practice. Malaysia.

xxvii. Unicef (2016). The impact of language policy practices on children's learning. Tanzania

xxviii. U.R.T (2014). Education and Training Policy. Dar es Salaam. Tanzania

xxix. Vygotsky, L.S (1978). Mind In Society: The Development Of Higher Psychological Processes. Cambridge, MA: Harvard University Press. 1978. 